\title{
On the Fluorescent, Steric and Electronic Factors Affecting the Detection of Metallic Ions Using an Imidazolyl-Phenolic Derived Fluorescent Probe
}

\author{
Ronaldo B. Orfão Jr., Fabrício de Carvalho, Paula Homem-de-Mello and \\ Fernando H. Bartoloni*
}

\author{
Centro de Ciências Naturais e Humanas, Universidade Federal do ABC, \\ 09210-580 Santo André-SP, Brazil
}

\begin{abstract}
The imidazolyl-phenolic probe used at the present study has its photophysic properties regulated by a tautomeric equilibrium. After the absorption of a photon, an excited state intramolecular proton transfer process generates a ketonic species, responsible for the $440 \mathrm{~nm}$ emission (in $\mathrm{CH}_{3} \mathrm{CN} / \mathrm{H}_{2} \mathrm{O}$, 95:5, v/v). Addition of $\mathrm{Cu}^{2+}, \mathrm{Al}^{3+}, \mathrm{Cr}^{3+}$ and $\mathrm{Fe}^{3+}$ suppresses emission through a combination of dynamic and static-like quenching, as indicated by Stern-Volmer plots, with a higher sensitivity for $\mathrm{Cu}^{2+}\left(\mathrm{K}_{\mathrm{SV}}=1.90 \times 10^{5}\right.$ and $2.40 \times 10^{4} \mathrm{~L} \mathrm{~mol}^{-1}$, respectively, for $\mathrm{Cu}^{2+}$ and $\left.\mathrm{Fe}^{3+}\right)$. The trivalent ions led to the formation of a locked-enol tautomer that emits at shorter wavelengths; this coordinated compound is also quenched at metallic ions concentrations above $20 \mu \mathrm{mol} \mathrm{L} \mathrm{L}^{-1}$, due to a collisional process. When compared to another imidazolyl-phenolic probe, experimental and simulated data revealed that fluorescent, steric and electronic effects regulate their sensitivity towards the ions.
\end{abstract}

Keywords: ESIPT, tautomerization, fluorescent sensor, copper(II), iron(III)

\section{Introduction}

The development of chemosensors for the detection of metallic cations in solution is a current topic of research, which elegantly combines preparative organic chemistry and spectroscopic studies, with the ultimate goal of applying such sensors for biological and environmental purposes. ${ }^{1-3}$ Fluorescent probes are frequently used as the detection unit of chemosensors, combined with a recognition unit; ${ }^{4}$ nonetheless, some fluorescent probes may act as a single detection/recognition system. In either case, the chemosensor efficiency depends on how strong is the binding interaction of the sensor with the metallic ion in solution. The presence of the latter can be indicated by changes on the properties of the free fluorescent sensor, such as the emission wavelength and/or intensity, or the appearance of a new band due to coordination of the sensor with the metallic cation. ${ }^{5,6}$

Generally, chemosensors are based on a switching on/ off mechanism, ${ }^{7}$ such that there is a relationship between emission intensity and metallic ion concentration. Switching on mechanism occurs when an increased concentration of metallic ions enhances the emission intensity of the fluorescent sensor. ${ }^{8}$ In the opposite way, switching off

*e-mail: fernando.bartoloni@ufabc.edu.br mechanism is the quenching effect of the emission intensity with increasing concentration of metal ions. ${ }^{3}$ In recent years, ${ }^{9-13}$ several chemosensors were reported to operate based on an excited state intramolecular proton transfer (ESIPT, Scheme 1) process. The ESIPT process can be interpreted as the disturbance of the equilibrium between two tautomers, the enolic $(\mathrm{E})$ and ketonic $(\mathrm{K})$ species, that happens after absorption of a photon. Such phenomenon occurs with an imidazolyl-phenolic framework, ${ }^{7}$ as the one present in 2-(4,5-diphenyl-1H-imidazol-2-yl)phenol $(\mathbf{1})^{14}$ and its derivative 2,4-di-tert-butyl-6-(4,5-diphenyl- $1 \mathrm{H}$ imidazol-2-yl)phenol (2). ${ }^{13}$ The phototautomerization reaction occurs once that the $\mathrm{E}_{0}$ tautomer is the most stable on the fundamental state (when compared to $\mathrm{K}_{0}$ ) and, after the formation of the excited state $\mathrm{E}_{1}$, the ESIPT process generates the more stable electronically excited tautomer $\mathrm{K}_{1}$. After deactivation of the $\mathrm{K}_{1}$ state through the emission of a photon, the system thermally equilibrates from $\mathrm{K}_{0}$ back to the more stable $\mathrm{E}_{0}$ species. Since there is a wide difference in the energy levels of the enolic $\left(\mathrm{E}_{0} \rightarrow \mathrm{E}_{1}\right)$ and ketonic $\left(\mathrm{K}_{1} \rightarrow \mathrm{K}_{0}\right)$ species, this system displays a large Stokes shift (regularly, greater than $100 \mathrm{~nm}){ }^{7}$ This results in the non-existence of an overlap of the emission and absorption bands, making these promising compounds for use as fluorescent probes. ${ }^{15}$ The presence of certain metallic ions induces the formation of a complex, which prevents 
the formation of the ketonic species and, thus, the ESIPT process is inhibited, changing the emission profile of the probe (Scheme 1). ${ }^{7,13}$

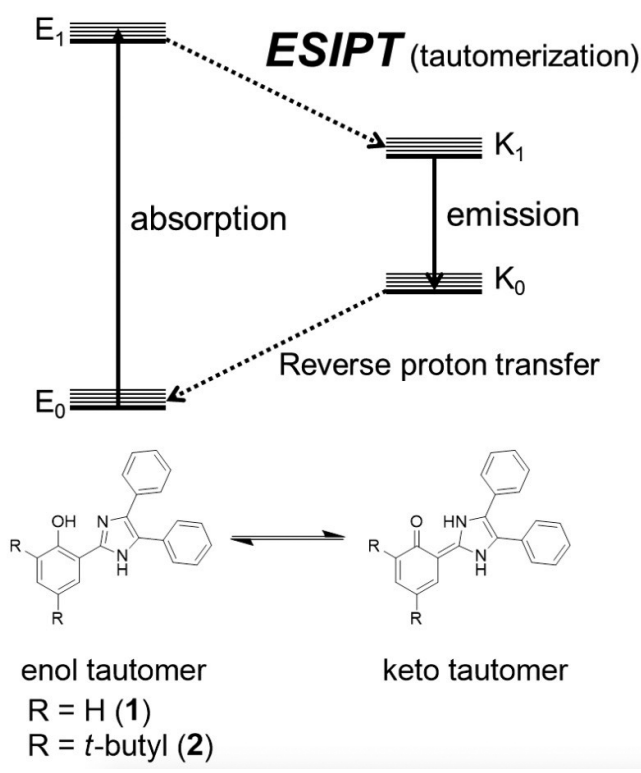

Scheme 1. Keto-enol tautomerism for imidazolyl-phenolic derivatives (1 and 2), with the illustrative relative energy levels of the fundamental and excited electronic states of the enolic (E) and ketonic (K) species (adapted from reference 14).

Our research group recently reported the application of compound $\mathbf{2}$ as a fluorescent sensor to $\operatorname{detect} \mathrm{Al}^{3+}, \mathrm{Cr}^{3+}$, $\mathrm{Fe}^{3+}$ and $\mathrm{Cu}^{2+}$ ions ${ }^{13}$ which occurs due to the formation of a complex and inhibition of the ESIPT process, thus, quenching the ketonic species emission. Moreover, the interaction between $\mathbf{2}$ and the aforementioned trivalent cations results on a new emission band, attributed to the fluorescence of a locked-enol tautomer, stabilized due to coordination..$^{13}$ In this sense, it can be said that chemosensor $\mathbf{2}$ works through a simultaneous switching on/off mechanism, with both quenching and enhancing of emission signals occurring at the same system, a desirable aspect of any sort of chemosensor. ${ }^{7}$ However, the presence of the tert-butyl groups in $\mathbf{2}$ enhances the low-lying vibrational/rotational modes available to absorb the excess energy, resulting on a low fluorescence quantum yield $\left(\Phi_{\mathrm{FL}}<0.1\right)$ of the probe. ${ }^{16}$ The non-existence of this so-called free rotor effect ${ }^{16}$ in compound $\mathbf{1}$ can potentially increase its $\Phi_{\mathrm{FL}}$, when compared to probe $\mathbf{2}$, and this may have a positive feedback on the sensitivity of this system to detect metallic ions. The synthesis of compound $\mathbf{1}$ has been previously reported in many studies, ${ }^{14,17,18}$ as well as its photophysical properties in methanol, dimethylformamide, tetrahydrofuran ${ }^{14}$ and acetonitrile, ${ }^{18}$ with comments made on its ESIPT behavior. ${ }^{14}$ Although the interaction of $\mathbf{1}$ with $\mathrm{Zn}^{2+},{ }^{14} \mathrm{Co}^{2+},{ }^{17}$ and $\mathrm{Cu}^{2+}{ }^{18}$ has been previously investigated, the disturbance of this probe's keto/enol tautomerism, as evidenced by a Stern-Volmer approach, has never been applied for the detection of metallic ions in solution. To further increase our understanding concerning the interaction of the imidazolyl-phenolic framework with metallic cations, in this work we have studied the fluorescence quenching of probe $\mathbf{1}$ by $\mathrm{Cu}^{2+}, \mathrm{Al}^{3+}, \mathrm{Cr}^{3+}$ or $\mathrm{Fe}^{3+}$ (as their nitrate salts), in an acetonitrile/water, 95:5, v/v media. The Stern-Volmer treatment of the data indicates that two quenching processes, a collisional and an unusual static-like one, are responsible for the probe's response towards the metallic ions. We have observed that fluorescent sensor $\mathbf{1}$ is more sensitive to the presence of these metallic ions than the tert-butyl derivative $\mathbf{2}$, previously studied by our group, ${ }^{13}$ even these two probes bearing the same imidazolyl-phenolic framework. Expanding what has been done before, the analysis proposed herein suggests that this is due to a combination of factors: the higher fluorescence quantum yield of probe $\mathbf{1}$ and a reduced steric hindrance, with simultaneous increased nucleophilicity, of its coordination site, the latter evidenced by simulated electrostatic potential maps.

\section{Experimental}

UV-Vis absorption spectra were recorded on a Varian Cary 60 with a multicell holder thermostatized at $25^{\circ} \mathrm{C}$ by a Varian Cary PCB 1500 system. Fluorescence spectra were recorded on a Varian Cary Eclipse (PMT voltage set at $650 \mathrm{~V}$; both excitation and emission slits at $2.5 \mathrm{~nm}$ ) with a single-cell holder thermostatized by a Varian Cary PCB 1500 system. Infrared spectrum was recorded on a PerkinElmer FTIR Spectrum Two coupled to an UATR Two accessory, used for measurements of the sample in the solid state. Gas chromatography coupled to low resolution mass spectrometry (GC-MS) analysis were performed on a Varian 4000, with electron impact ionization, an ion trap analyzer and a CP-8400 automated sampler. CHN composition was obtained in a PerkinElmer CHN 2400 analyzer, using benzoic acid as standard. Nuclear magnetic resonance (NMR) spectra was obtained at $25^{\circ} \mathrm{C}$ on a Bruker AIII $500 \mathrm{MHz}$ spectrometer; chemical shifts $(\delta)$ are reported in parts per million (ppm) relative to tetramethylsilane (TMS). For the spectroscopic assays with metal ions, the following method was applied: to a mixture of $\mathrm{CH}_{3} \mathrm{CN} / \mathrm{H}_{2} \mathrm{O}, 95: 5$, v/v, contained in a quartz cuvette for absorbance or emission, already charged with $\mathbf{1}$ (ca. $10^{-6} \mathrm{~mol} \mathrm{~L}^{-1}$ final concentration, added as a $9.0 \times 10^{-3} \mathrm{~mol} \mathrm{~L}^{-1}$ stock solution in $\mathrm{CH}_{3} \mathrm{CN}$ ), sequential additions of small volumes of the nitrate salts stock solutions were made, without causing significant changes to the final 
$3.0 \mathrm{~mL}$ solution volume. The absorption or fluorescence spectra $\left(\lambda_{\mathrm{ex}}=310 \mathrm{~nm}\right)$ were recorded fifteen minutes after the preparation of each solution. Relative fluorescence quantum yields $\left(\Phi_{\mathrm{FL}}\right)$ were measured by integration of the corrected emission spectra relative to 2,4-di-tert-butyl6-(4,5-diphenyl-1H-imidazol-2-yl)phenol (2) in ethyl acetate as a standard $\left(\Phi_{\mathrm{FL}}=0.11\right)$, after applying correction for the refractive indices of the solvents. ${ }^{19}$

2-(4,5-Diphenyl-1H-imidazol-2-yl)phenol (1) was prepared and isolated according to the procedure described by Benisvy et al. ${ }^{20} \mathrm{~A} 50 \mathrm{~mL}$ single neck round-bottomed flask was charged with a mixture of salicylaldehyde $(8.8 \mathrm{mmol})$, benzil $(8.6 \mathrm{mmol})$ and ammonium acetate (64 mmol), in $30 \mathrm{~mL}$ of glacial acetic acid. After 2 hours of reflux the reaction was cooled to room temperature and a colorless precipitate was obtained. Afterwards, $30 \mathrm{~mL}$ of ice-cold deionized water were added; the crude product was collected by vacuum-filtration, washed with water $(5 \times 15 \mathrm{~mL})$ and dried by suction. The resulting solid was dissolved in $\mathrm{CH}_{2} \mathrm{Cl}_{2}$ and dried under $\mathrm{MgSO}_{4}$. The solution was filtered and the solvent removed by rotary evaporation, yielding a solid that was purified by recrystallization from $\mathrm{CH}_{2} \mathrm{Cl}_{2}$ /pentane (1.15 g, $42 \%$ yield). Elemental analysis calcd. for $\mathrm{C}_{21} \mathrm{H}_{16} \mathrm{~N}_{2} \mathrm{O}: \mathrm{C}, 85.1 ; \mathrm{H}, 5.4 ; \mathrm{N}, 9.5 \%$; found: $\mathrm{C}$, 84.5; H, 5.4; N, 9.3\%; mp 200.5-201.2 ${ }^{\circ} \mathrm{C}\left(200-201{ }^{\circ} \mathrm{C}\right) ; ;^{14}$ IR (solid state) $v / \mathrm{cm}^{-1} 3192,3057,1600,1539,1138,1071$; ${ }^{1} \mathrm{H}$ NMR (500 MHz, DMSO- $d_{6}$ ) $\delta 6.96$ (m, 2H), 7.25-7.29 (m, 4H), 7.42-7.55 (m, 7H), 8.04 (dd, 1H), $12.96(\mathrm{~s}, 1 \mathrm{H})$, 13.04 (s, $1 \mathrm{H}) ;{ }^{13} \mathrm{C}$ NMR $\left(125 \mathrm{MHz}\right.$, DMSO- $\left.d_{6}\right) \delta 112.84$, $116.81,118.85,124.93,126.77,127.05,127.28,128.31$, $128.50,128.77,130.07,130.24,133.58,134.11,145.83$ 156.67; MS (EI, +): $m / z$, observed: $312.2 ; \mathrm{C}_{21} \mathrm{H}_{16} \mathrm{~N}_{2} \mathrm{O}[\mathrm{M}]^{+}$ requires: 312.13 . Spectra for the GC-MS (Figure S1), IR (Figure S2) and NMR (Figure S3 for ${ }^{1} \mathrm{H}$ and Figure S4 for ${ }^{13} \mathrm{C}$ ) analysis are presented in the Supplementary Information.

Quantum mechanical calculations were used to obtain structure in a minima of surface energy potential and to calculate the molecular electrostatic potential map (MEP) in ChelpG scheme as implemented in Gaussian-09 program, ${ }^{21}$ using density functional theory by means of Becke3-LeeYang-Parr (B3LYP) functional and 6-31G(2d,2p) basis set. In MEP plots, the negative regions regard nucleophilic sites, and the positive regions are electrophilic sites.

\section{Results and Discussion}

The fluorescent probe $\mathbf{1}$ presented absorption bands at 291 and $318 \mathrm{~nm}$, with a single emission band centered at $440 \mathrm{~nm}$ (Figure 1). This Stokes shift represents a $122 \mathrm{~nm}$ $\left(8719 \mathrm{~cm}^{-1}\right)$ difference, suggesting that, as expected, the excited state of the keto tautomer $\left(\mathrm{K}_{1}\right.$, Scheme 1) is responsible for the fluorescence emission of the free compound. ${ }^{7,13}$ It is known that $\mathbf{1}$ follows an ESIPT pathway after photoexcitation (Scheme 1), as previously reported on the literature for such compound ${ }^{14}$ and as seen for other substances sharing structural similarities. ${ }^{7,13,22,23}$ For comparison, probe 1 has maximum absorption and emission bands at 316 and $430 \mathrm{~nm}$, with a smaller $8390 \mathrm{~cm}^{-1}$ Stokes shift, when methanol is used as solvent. ${ }^{14}$ The tert-butyl containing derivative 2 studied by our group absorbs at 294 and $322 \mathrm{~nm}$ and emits at $466 \mathrm{~nm}$, also in acetonitrile/water, 95:5, v/v, comprising a $9597 \mathrm{~cm}^{-1}$ Stokes shift. ${ }^{13}$ The herein measured fluorescence quantum yields in acetonitrile/water, 95:5, v/v, media for compounds $\mathbf{1}$ and $\mathbf{2}$ were $\Phi_{\mathrm{FL}}=0.350$ and 0.013 , respectively. As stated in the Introduction section, the two tert-butyl groups increase the number of available vibrational/rotational modes that can absorb the excess excitation energy (free rotor effect),${ }^{16}$ consequently, the non-radiative decay through internal conversion is favored. Compound $\mathbf{1}$ has a $\Phi_{\mathrm{FL}}$ almost thirty times higher than $\mathbf{2}$ in the studied solvent mixture, thus, its application as fluorescent sensor can be explored for the detection of metallic cations due to its increased luminescent properties.

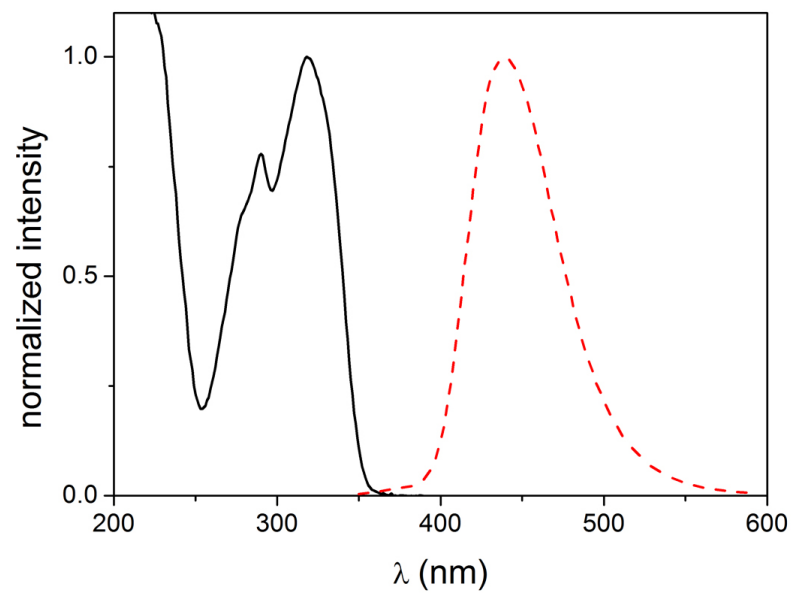

Figure 1. UV-Vis absorption (black line) and emission spectra (red dashed line) of $\mathbf{1}\left(\lambda_{\mathrm{ex}}=310 \mathrm{~nm}\right)$ in $\mathrm{CH}_{3} \mathrm{CN} / \mathrm{H}_{2} \mathrm{O}(95: 5, \mathrm{v} / \mathrm{v})$.

The free chemosensor $\mathbf{1}$ showed fluorescence emission at $440 \mathrm{~nm}$ in an acetonitrile/water, 95:5, v/v, media (Figure 1). The addition of the metallic ions $\mathrm{Ca}^{2+}, \mathrm{Co}^{2+}, \mathrm{Ni}^{2+}, \mathrm{Zn}^{2+}$ or $\mathrm{Ba}^{2+}$ (Figures S5-S9) did not induce any significant changes in the emission profile (Figure 2), indicating that in these conditions there is no interaction of the fluorescent sensor $\mathbf{1}$ with such metallic ions. These results differ from the ones obtained by Eseola et al. ${ }^{14}$ and Buchholz et al. ${ }^{17}$ who reported the titration and characterization of a coordinated compound between 1 and $\mathrm{Zn}^{2+}$ or $\mathrm{Co}^{2+}$, respectively. Eseola et al..$^{14}$ observed that the coordination of $\mathrm{Zn}^{2+}$ with $\mathbf{1}$ promoted a fluorescence 
emission quenching, when the reaction is carried out in methanol; 1 was used at a $1 \times 10^{-4} \mathrm{~mol} \mathrm{~L}^{-1}$ concentration and the quenching effect was reported on the 1 to $5 \times 10^{-8} \mathrm{~mol} \mathrm{~L}^{-1}$ concentration range of $\mathrm{Zn}^{2+}$. This is significantly different from our system, where no suppression was observed with 1 at $8 \times 10^{-6} \mathrm{~mol} \mathrm{~L}^{-1}$ with the addition of $\mathrm{Zn}^{2+}$ from $1 \times 10^{-6}$ to $2 \times 10^{-5} \mathrm{~mol} \mathrm{~L}^{-1}$. At the present study and at the one performed by Eseola et al.,$^{14}$ the complexation reaction occurred in situ spontaneously, however, Buchholz et al. ${ }^{17}$ had to apply reflux conditions to achieve coordination with $\mathrm{Co}^{2+}$ in ethanol. The present work proposes the application of 1 to detect metallic ions through a spontaneous complexation at ambient temperature; in our case, the interaction between probe 1 and $\mathrm{Zn}^{2+}$ or $\mathrm{Co}^{2+}$ in an acetonitrile/water, 95:5, v/v, media was not observed at any extent.

There is a substantial change in the emission profile of compound $\mathbf{1}$ in the presence of $\mathrm{Cu}^{2+}, \mathrm{Al}^{3+}, \mathrm{Cr}^{3+}$ or $\mathrm{Fe}^{3+}$ ions. Quenching of the $440 \mathrm{~nm}$ emission band was observed for these ions (Figure 2b) and in the presence of $\mathrm{Al}^{3+}, \mathrm{Cr}^{3+}$ and $\mathrm{Fe}^{3+}$ a new one originated around $385 \mathrm{~nm}$ (Figure 2c). The appearance of this new emission band indicates that coordination of the fluorescent probe with the ionic species has occurred in solution, ${ }^{7,24,25}$ generating a locked-enol tautomer (Scheme 2) which fluoresces at $385 \mathrm{~nm}$. It is expected that the locked-enol tautomer would emit at a shorter wavelength than the one for the free keto tautomer emission, due to the relative energy difference between the fundamental and excited states of these species (Scheme 1). ${ }^{13}$

\section{Effect of $\mathrm{Cu}^{2+}$ addition on the emission profile}

The successive addition of $\mathrm{Cu}^{2+}$ ions to a solution containing probe $\mathbf{1}$ caused a systematic decrease in the $440 \mathrm{~nm}$ emission band intensity (Figure 3a), with a fairly linear intensity $v s$. concentration relationship (Figure 3b). The emission band that appeared near $385 \mathrm{~nm}$ for the trivalent cations $\mathrm{Al}^{3+}, \mathrm{Cr}^{3+}$ or Fe $^{3+}$ (Figure 2c), regarding the formation of the locked-enol tautomer, was not observed within the used $\mathrm{Cu}^{2+}$ concentration range. Although this may suggest that the locked-enol species is not being generated with $\mathrm{Cu}^{2+}$, this is not the case. It seems that $\mathrm{Cu}^{2+}$ is very efficient in quenching the emission of the enolic tautomer as well, preventing the observation of its fluorescence; this has been previously addressed by our group for the interaction of probe 2 with $\mathrm{Cu}^{2+} .{ }^{13}$ From a correlation between $\log (\mathrm{I})$ and $\left[\mathrm{Cu}^{2+}\right]$ (data not shown) it was possible to determine the limit of detection (LOD) ${ }^{3}$ of $\mathrm{Cu}^{2+}$ in this fluorescent system, being obtained a LOD $=0.24 \mu \mathrm{mol} \mathrm{L}^{-1}$. Thus, the detection of $\mathrm{Cu}^{2+}$ ions through the fluorescence quenching of compound $\mathbf{1}$ has a higher sensitivity when compared to other fluorescent sensors for $\mathrm{Cu}^{2+}$ reported in
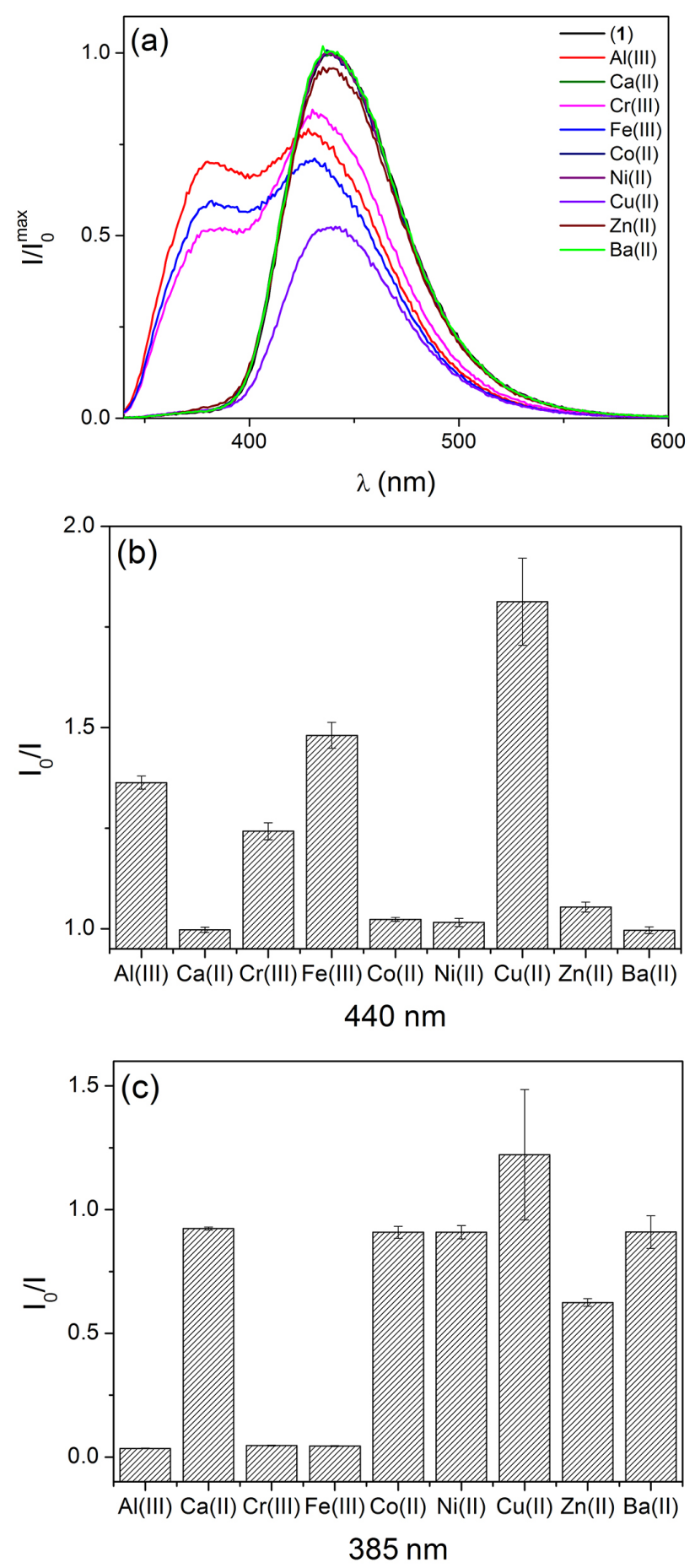

Figure 2. (a) Emission spectra of $\mathbf{1}\left(8.0 \times 10^{-6} \mathrm{~mol} \mathrm{~L}^{-1}, \lambda_{\text {ex }}=310 \mathrm{~nm}\right)$ in $\mathrm{CH}_{3} \mathrm{CN} / \mathrm{H}_{2} \mathrm{O}\left(95 / 5\right.$, v/v) with the addition of $\mathrm{Al}^{3+}\left(1.8 \times 10^{-5} \mathrm{~mol} \mathrm{~L}^{-1}\right)$; $\mathrm{Ca}^{2+}\left(1.1 \times 10^{-5} \mathrm{~mol} \mathrm{~L}-1\right) ; \mathrm{Cr}^{3+}\left(2.8 \times 10^{-5} \mathrm{~mol} \mathrm{~L}^{-1}\right) ; \mathrm{Fe}^{3+}\left(1.9 \times 10^{-5} \mathrm{~mol} \mathrm{~L}^{-1}\right)$; $\mathrm{Co}^{2+}\left(2.5 \times 10^{-5} \mathrm{~mol} \mathrm{~L}^{-1}\right) ; \mathrm{Ni}^{2+}\left(1.7 \times 10^{-5} \mathrm{~mol} \mathrm{~L}^{-1}\right) ;$ $\mathrm{Cu}^{2+}\left(5.8 \times 10^{-5} \mathrm{~mol} \mathrm{~L}^{-1}\right) ; \mathrm{Zn}^{2+}\left(1.4 \times 10^{-5} \mathrm{~mol} \mathrm{~L}^{-1}\right)$; $\mathrm{Ba}^{2+}\left(1.6 \times 10^{-5} \mathrm{~mol} \mathrm{~L}^{-1}\right)$. Changes on the emission profile due to the addition of metallic ions were followed particularly at (b) 440 and (c) $385 \mathrm{~nm}$.

the literature, with LOD values as $0.86,{ }^{13} 1.15,{ }^{3} 69.0^{26}$ and $130.0 \mu \mathrm{mol} \mathrm{L}{ }^{-1} .{ }^{27}$ Care should be taken when different LOD values are compared, once that different solvent systems 


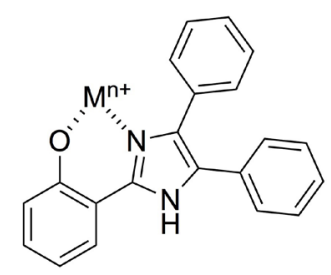

Scheme 2. Formation of the so-called locked-enol tautomer due to coordination of 1 with a generic metallic cation $\mathrm{M}^{\mathrm{n}+}$ (adapted from reference 13).

may be involved; for example, the aforementioned 69.0 and $130.0 \mu \mathrm{mol} \mathrm{L}^{-1}$ values for $\mathrm{Cu}^{2+}$ detection where determined in $\mathrm{CH}_{3} \mathrm{CN} / \mathrm{H}_{2} \mathrm{O}, 75: 25(\mathrm{v} / \mathrm{v})$ and methanol, respectively, which are more polar than the $\mathrm{CH}_{3} \mathrm{CN} / \mathrm{H}_{2} \mathrm{O}, 95: 5(\mathrm{v} / \mathrm{v})$ media used at the present study.
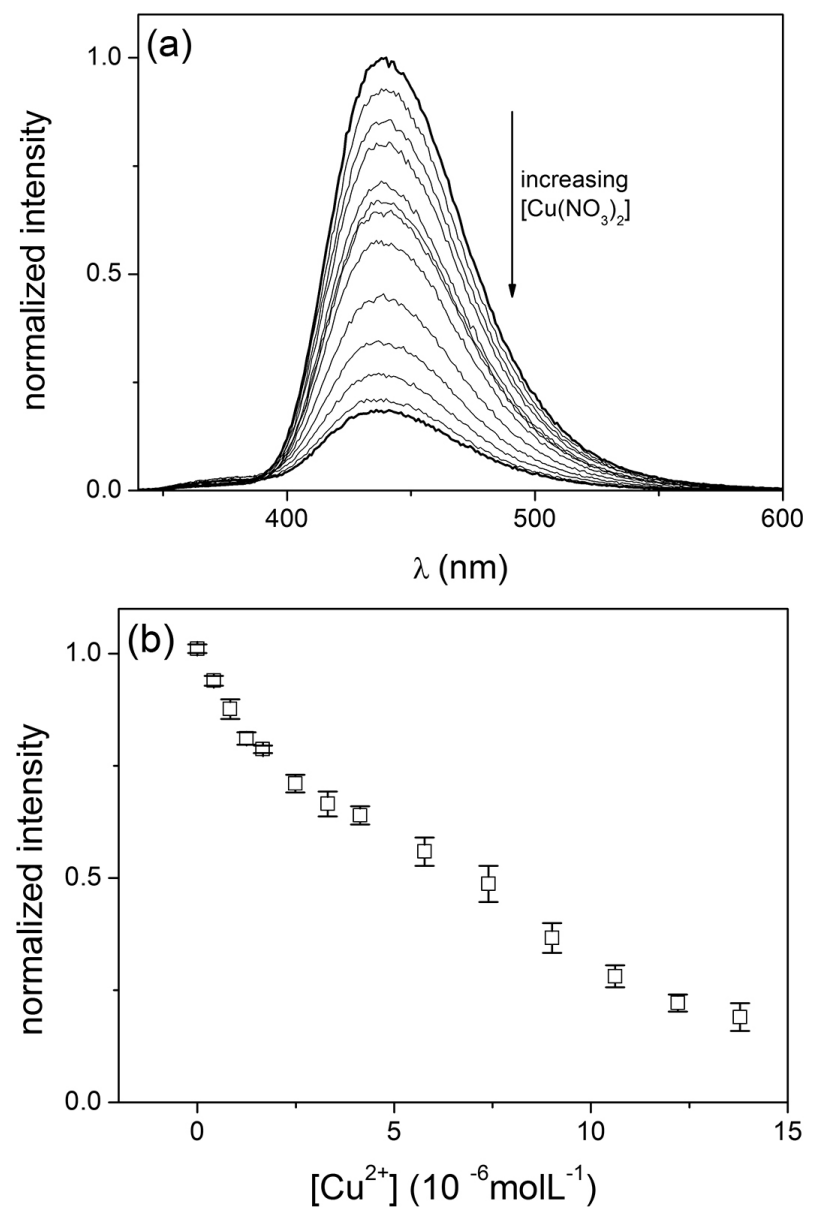

Figure 3. Effect of $\mathrm{Cu}^{2+}$ concentration $\left(4.2 \times 10^{-7}\right.$ to $\left.1.4 \times 10^{-5} \mathrm{~mol} \mathrm{~L}^{-1}\right)$ on the fluorescence emission profile of $\mathbf{1}\left(\lambda_{\mathrm{ex}}=310 \mathrm{~nm}\right)$ (a), which showed a linear decrease on the $440 \mathrm{~nm}$ maximum with increasing concentration of the metallic ion (b).

To further understand the types of interaction between 1 and $\mathrm{Cu}^{2+}$ that can lead to fluorescence quenching, the obtained data was analyzed through a Stern-Volmer treatment (Figure 4). The observed upward curvature of this Stern-Volmer plot is an experimental evidence for the occurrence of both collisional and static quenching processes. ${ }^{3,13,28}$ A reasonable linear relationship $(\mathrm{r}=0.985)$ was observed until $1.7 \times 10^{-6} \mathrm{~mol} \mathrm{~L}^{-1}$ of $\mathrm{Cu}^{2+}$, furnishing a Stern-Volmer constant $\mathrm{K}_{\mathrm{SV}}=(1.90 \pm 0.10) \times 10^{5} \mathrm{~L} \mathrm{~mol}^{-1}$.

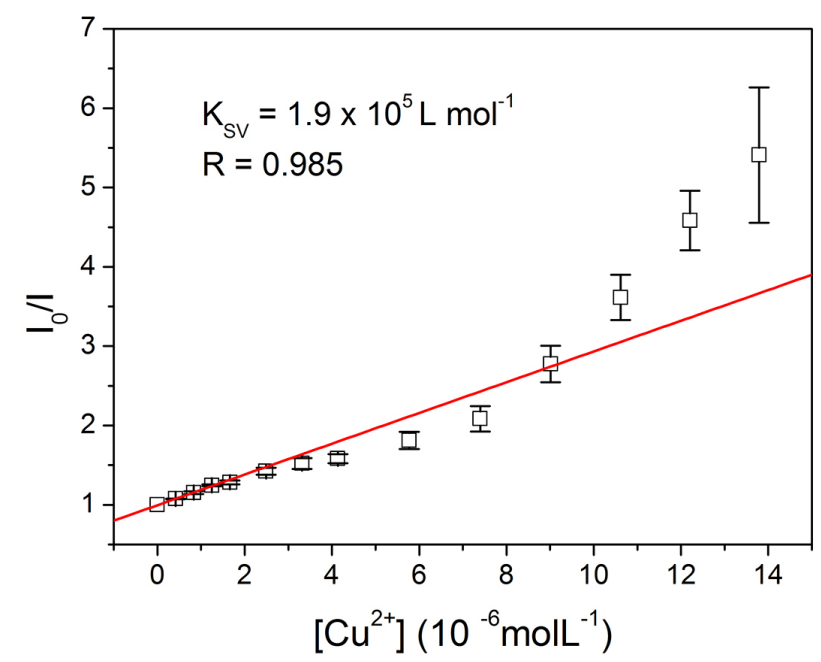

Figure 4. Stern-Volmer plot for the quenching emission at $440 \mathrm{~nm}$, for the interaction of $\mathbf{1}$ with $\mathrm{Cu}^{2+}$ ion.

Effect of $\mathrm{Al}^{3+}, \mathrm{Cr}^{3+}$ and $\mathrm{Fe}^{3+}$ addition on the emission profile

Probe $\mathbf{1}$ presented a very similar response upon addition of $\mathrm{Al}^{3+}, \mathrm{Cr}^{3+}$ or $\mathrm{Fe}^{3+}$ ions to its solution, namely, a marked emission quenching at $440 \mathrm{~nm}$ and the appearance of a new emission band around $385 \mathrm{~nm}$ (Figures 5a-5c). As performed for $\mathrm{Cu}^{2+}$, we have determined the LOD values for $\mathrm{Al}^{3+}, \mathrm{Cr}^{3+}$ and $\mathrm{Fe}^{3+}$, which are 1.07, 3.21 and $3.50 \mu \mathrm{mol} \mathrm{L} \mathrm{L}^{-1}$, respectively. The fluorescence sensor reported in this study exhibited a higher sensitivity for the detection of $\mathrm{Fe}^{3+}$ when compared to the previously studied compound $\mathbf{2}$ $\left(\mathrm{LOD}=11.0 \mu \mathrm{mol} \mathrm{L}{ }^{-1}\right) .{ }^{13}$ Near $385 \mathrm{~nm}$, the observed rise in emission intensity with increasing metallic ion concentration can be attributed to the augmentation of the locked-enol tautomer concentration. ${ }^{13}$ The fluorescence emission of such enolic species increases until it reaches a maximum value for a given concentration of cation, which is similar amid the three trivalent ions: 18,20 and $20 \mu \mathrm{mol} \mathrm{L}^{-1}$ for $\mathrm{Al}^{3+}$, $\mathrm{Cr}^{3+}$ and $\mathrm{Fe}^{3+}$, respectively (Figure 5d). A further increase in concentration promotes a decrease on the emission intensity near $385 \mathrm{~nm}$, suggesting that the locked-enol tautomer suffers from a dynamic quenching by the cation (Figure $5 \mathrm{~d}$ ). This is observable only above a certain cation concentration once that, until that point, the added metallic ion is involved mainly on the formation of the fluorescent locked-enol tautomer, and not on its quenching, which is prominent only at higher concentrations. We were able to determine the Stern-Volmer constant $\left(\mathrm{K}_{\mathrm{SV}}\right)$ values for the $\mathrm{Al}^{3+}, \mathrm{Cr}^{3+}$ and $\mathrm{Fe}^{3+}$ ions for the fluorescence quenching near $385 \mathrm{~nm}$ (Figure 5e, Table 1), 
on the cation concentration interval where it was observed (above $20 \mu \mathrm{mol} \mathrm{L}{ }^{-1}$ ).

As shown in Figure 6a, the addition of $\mathrm{Fe}^{3+}$ decreases the emission intensity at $440 \mathrm{~nm}$ at the entire concentration range. This quenching at $440 \mathrm{~nm}$ was also observed with $\mathrm{Al}^{3+}$ and $\mathrm{Cr}^{3+}$ ions, however, this effect is not observed at
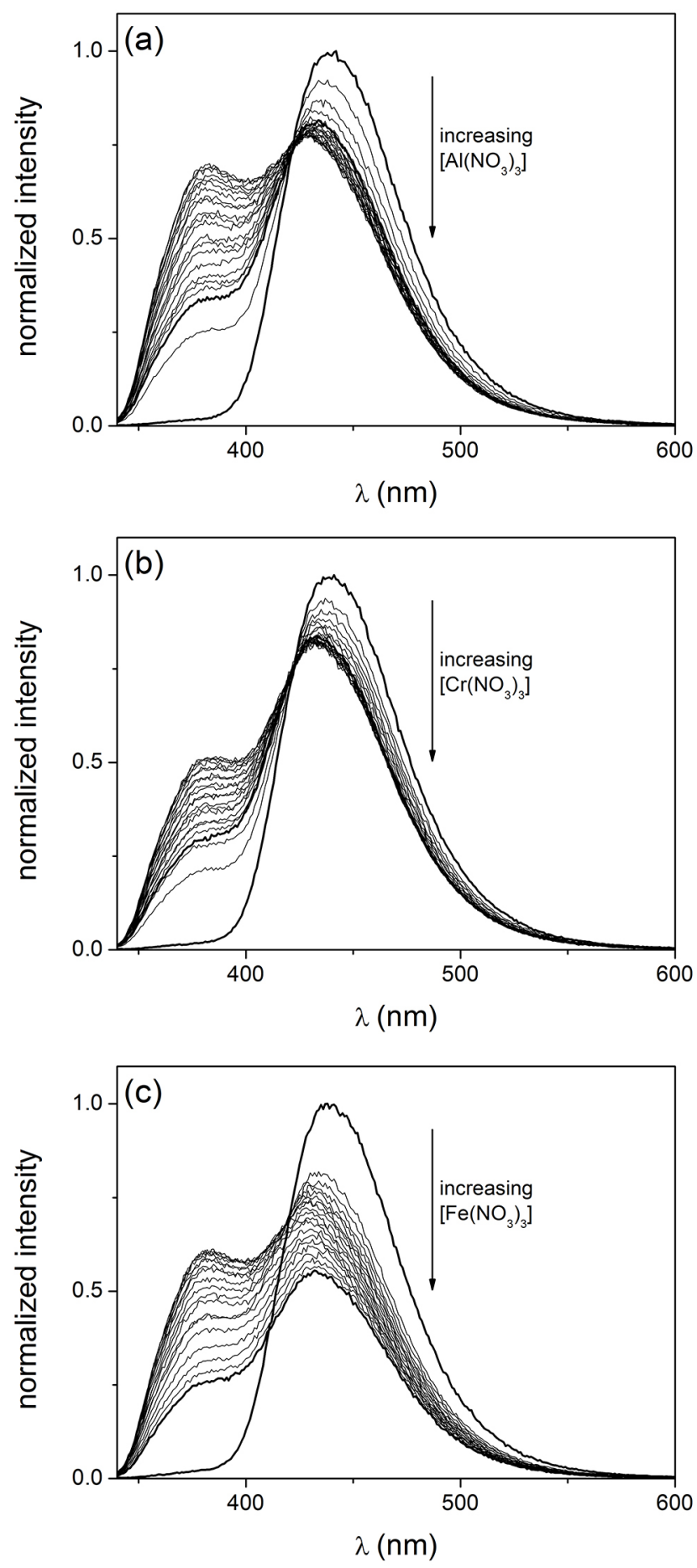

concentrations higher than 15 and $18 \mu \mathrm{mol} \mathrm{L}{ }^{-1}$, respectively (Figure 6a). For a cation concentration of up to $15 \mu \mathrm{mol} \mathrm{L}^{-1}$, where suppression is observed for the three trivalent ions, the Stern-Volmer constant $\left(\mathrm{K}_{\mathrm{SV}}\right)$ values at $440 \mathrm{~nm}$ were determined (Figure 6b, Table 2), all at the $10^{4} \mathrm{~L} \mathrm{~mol}^{-1}$ order of magnitude. A reasonable linear relationship $(r=0.990)$ was
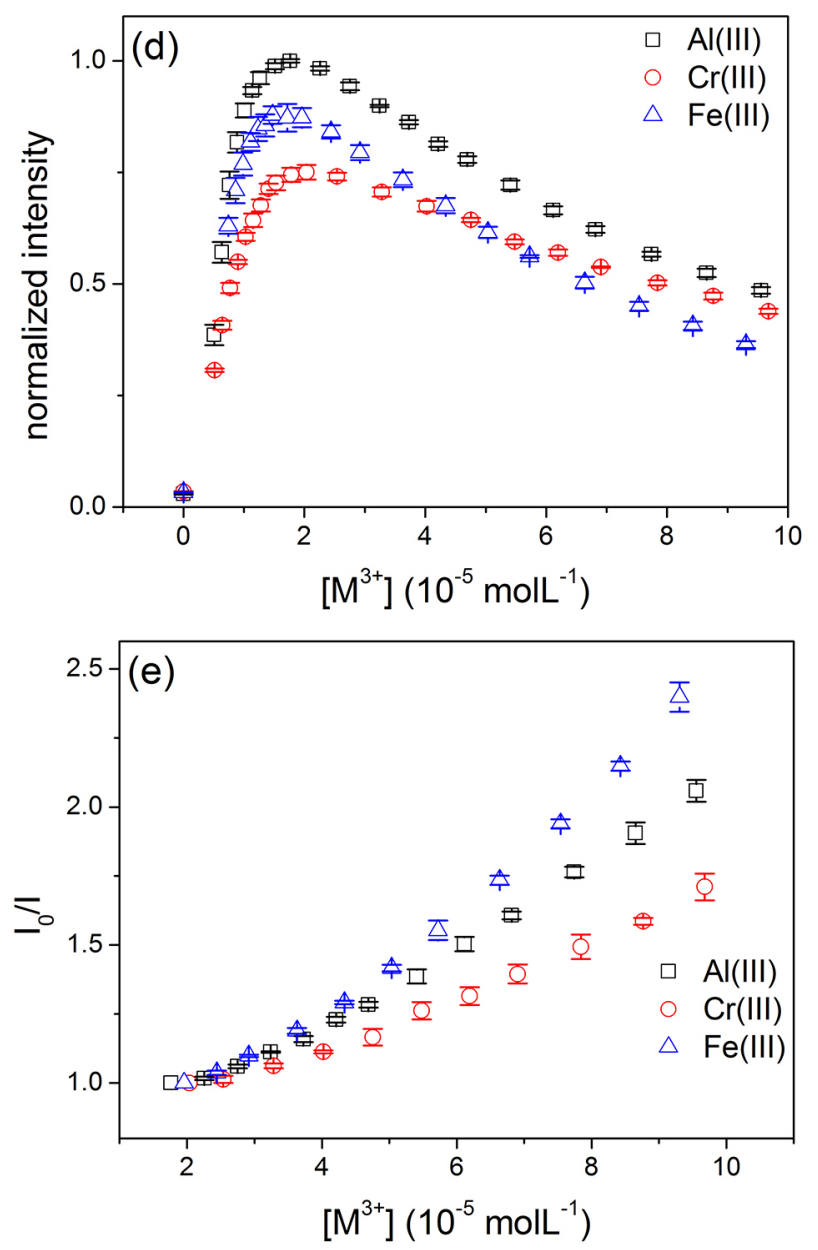

Figure 5. Effect of the (a) $\mathrm{Al}^{3+}\left(5.1 \times 10^{-6}\right.$ to $\left.9.6 \times 10^{-5} \mathrm{~mol} \mathrm{~L}^{-1}\right)$; (b) $\mathrm{Cr}^{3+}\left(5.1 \times 10^{-6}\right.$ to $\left.9.7 \times 10^{-5} \mathrm{~mol} \mathrm{~L}^{-1}\right)$ and $(\mathrm{c}) \mathrm{Fe}^{3+}\left(7.4 \times 10^{-6}\right.$ to $\left.9.3 \times 10^{-5} \mathrm{~mol} \mathrm{~L}^{-1}\right)$ concentrations on the fluorescence emission profile of $\mathbf{1}\left(\lambda_{\mathrm{ex}}=310 \mathrm{~nm}\right)$; (d) fluorescence emission intensity $v s$. [M $\left.{ }^{3+}\right]$ at 382 , 385 and $381 \mathrm{~nm}$; (e) Stern-Volmer plots for the fluorescence emission quenching at 382,385 and $381 \mathrm{~nm}$. 
Table 1. Stern-Volmer data for the quenching near $385 \mathrm{~nm}$, for the interaction of 1 with different metallic cations

\begin{tabular}{lccc}
\hline Metallic ion & $\begin{array}{c}\mathrm{K}_{\mathrm{SV}} / \\
\left(10^{4} \mathrm{~L} \mathrm{~mol}{ }^{-1}\right)\end{array}$ & $\begin{array}{c}{\left[\mathrm{M}^{3+}\right]_{\max }{ }^{\mathrm{a}} /} \\
\left(10^{-5} \mathrm{~mol} \mathrm{~L}^{-1}\right)\end{array}$ & $\mathrm{r}$ \\
\hline $\mathrm{Al}^{3+}$ & $1.09 \pm 0.05$ & 4.7 & 0.990 \\
$\mathrm{Cr}^{3+}$ & $0.95 \pm 0.03$ & 8.8 & 0.990 \\
$\mathrm{Fe}^{3+}$ & $1.40 \pm 0.05$ & 5.0 & 0.994 \\
\hline
\end{tabular}

${ }^{\mathrm{a}}\left[\mathrm{M}^{3+}\right]_{\max }$ is the maximum metallic ion concentration featuring in the linear Stern-Volmer treatment.

also observed for the 2.9 to $9.3 \times 10^{-5} \mathrm{~mol} \mathrm{~L}^{-1}$ concentration range of $\mathrm{Fe}^{3+}$, furnishing a second Stern-Volmer constant value of $\mathrm{K}_{\mathrm{SV}}=(4.70 \pm 0.20) \times 10^{3} \mathrm{~L} \mathrm{~mol}^{-1}$. It is not clear as to why there is an apparent second $\mathrm{K}_{\mathrm{SV}}$ constant at higher $\mathrm{Fe}^{3+}$ concentrations, since the Stern-Volmer profile of combined static and dynamic quenching usually shows an upward curvature, as seen for the enol tautomer quenching at $385 \mathrm{~nm}$ (Figure 5e), since these processes occur concurrently and not sequentially. When quenching occurs only by one of these mechanisms, straight-line Stern-Volmer plots are observed with the emission intensity dependence with ion concentration. ${ }^{28}$ Thus, to the best of our knowledge, it could be inferred that the emission suppression of the locked-enol tautomer (at $385 \mathrm{~nm}$, Figure 5e) does actually occur by a combination of static and dynamic quenching, whilst the emission suppression of the keto tautomer (at $440 \mathrm{~nm}$, Figure 6 b) occurs by an unusual static-like process. This is referred to as "static-like", since a formal static quenching would produce a non-fluorescent complex, which is not the case here, since the complex being generated is the fluorescent locked-enol tautomer.

Thus, the emission suppression observed at $440 \mathrm{~nm}$ shows a straight-line Stern-Volmer plot due to the formation of the locked-enol tautomer, and the concentration region where the phenomenon is observed further justifies this hypothesis: suppression of the emission at $440 \mathrm{~nm}$ occurs for the three trivalent cations for concentrations of up to $15 \mu \mathrm{mol} \mathrm{\textrm {L } ^ { - 1 }}$ of the metal ion, which is close to the concentration range where the emission of the locked-enol tautomer at $385 \mathrm{~nm}$ stops to rise, since this emission band is associated to its formation, and starts to be suppressed by the cation itself (Figure 5d). Therefore, the fluorescence behavior of probe $\mathbf{1}$ in the presence of the trivalent cations $\mathrm{Al}^{3+}, \mathrm{Cr}^{3+}$ and $\mathrm{Fe}^{3+}$ can be summarized as follows. From zero to $15-20 \mu \mathrm{mol} \mathrm{L}{ }^{-1}$ of cation the emission intensity in $440 \mathrm{~nm}$ decreases (Figure 6a) due to formation of the locked-enol tautomer, following a static-like quenching process $\left(\mathrm{K}_{\mathrm{Sv}}\right.$ approx. $10^{4} \mathrm{~L} \mathrm{~mol}^{-1}$, Table 2) that induces the appearance and increase of an emission signal around $385 \mathrm{~nm}$ (Figure 5d). For cations concentrations above $15-20 \mu \mathrm{mol} \mathrm{L}{ }^{-1}$, the locked-enol
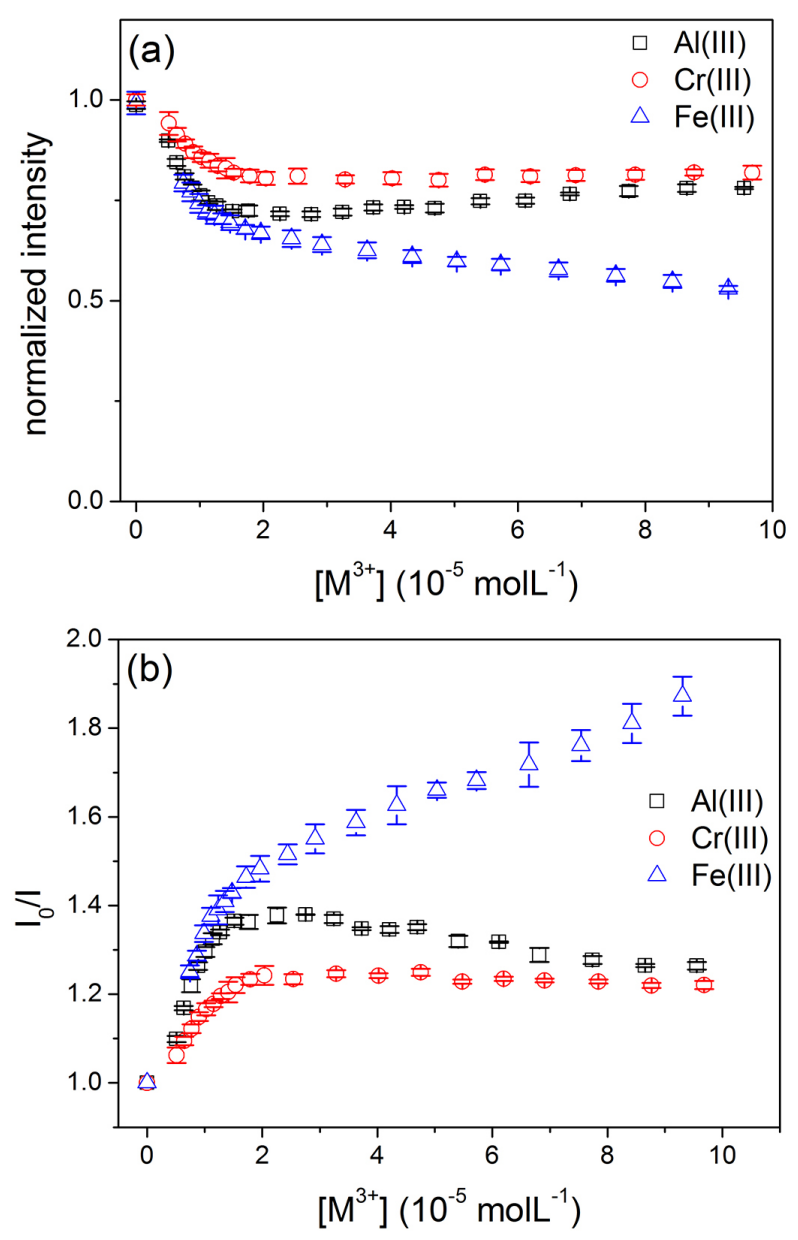

Figure 6. (a) Fluorescence emission intensity vs. $\left[\mathrm{M}^{3+}\right]$ at $440 \mathrm{~nm}$; (b) Stern-Volmer plots for the fluorescence emission quenching at $440 \mathrm{~nm}$, for the interaction of $\mathbf{1}$ with $\mathrm{Al}^{3+}, \mathrm{Cr}^{3+}$ and $\mathrm{Fe}^{3+}$ ions.

tautomer emission starts to be suppressed by a combination of static and collisional quenching, as evidenced by the shape of the Stern-Volmer plots around $385 \mathrm{~nm}$ (Figure 5e). When the concentration of $\mathrm{Al}^{3+}$ and $\mathrm{Cr}^{3+}$ is above 15 and $18 \mu \mathrm{mol} \mathrm{L}{ }^{-1}$, respectively, there is no further suppression of the keto tautomer emission at $440 \mathrm{~nm}$ (Figure 6a). However, with $\mathrm{Fe}^{3+}$, a second dynamic quenching process $\left(\mathrm{K}_{\mathrm{SV}}\right.$ approx. $10^{3} \mathrm{~L} \mathrm{~mol}^{-1}$ ) further suppresses the fluorescence emission of the keto tautomer (Figure 6b). We have previously observed that the suppression of the keto tautomer emission of compound 2 occurs only with $\mathrm{Fe}^{3+}$, and not with $\mathrm{Al}^{3+}$ or $\mathrm{Cr}^{3+},{ }^{13}$ showing that this metallic cation, in particular, has a higher potential to interact with probes based on an imidazolylphenolic system, such as $\mathbf{1}$ and $\mathbf{2}$.

Interaction of imidazolyl-phenolic systems $\mathbf{1}$ and $\mathbf{2}$ with metallic cations

It is interesting to perform a more direct comparison between data obtained for the fluorescent sensors $\mathbf{1}$ and, 
Table 2. Stern-Volmer data for the quenching at $440 \mathrm{~nm}$, for the interaction of $\mathbf{1}$ with different metallic cations

\begin{tabular}{lccc}
\hline Metallic ion & $\begin{array}{c}\mathrm{K}_{\mathrm{SV}} / \\
\left(10^{4} \mathrm{~L} \mathrm{~mol}^{-1}\right)\end{array}$ & $\begin{array}{c}{\left[\mathrm{M}^{3+}\right]_{\max }{ }^{\mathrm{a}} /} \\
\left(10^{-5} \mathrm{~mol} \mathrm{~L}^{-1}\right)\end{array}$ & $\mathrm{r}$ \\
\hline $\mathrm{Al}^{3+}$ & $3.00 \pm 0.30$ & 1.3 & 0.958 \\
$\mathrm{Cr}^{3+}$ & $1.52 \pm 0.09$ & 1.5 & 0.969 \\
$\mathrm{Fe}^{3+}$ & $2.40 \pm 0.20$ & 1.5 & 0.963 \\
\hline
\end{tabular}

${ }^{\mathrm{a}}\left[\mathrm{M}^{3+}\right]_{\max }$ is the maximum metallic ion concentration featuring in the linear Stern-Volmer treatment.

from our previous work, $2 .{ }^{13}$ The substitution of hydrogen by the tert-butyl group significantly decreases the sensitivity of the system for detection of $\mathrm{Cu}^{2+}, \mathrm{Al}^{3+}, \mathrm{Cr}^{3+}$ and $\mathrm{Fe}^{3+}$ ions in the studied $\mathrm{CH}_{3} \mathrm{CN} / \mathrm{H}_{2} \mathrm{O}(95: 5, \mathrm{v} / \mathrm{v})$ media, as seen for the overall decrease in $\mathrm{K}_{\mathrm{Sv}}$ and increase in LOD values obtained with sensor $\mathbf{2} .{ }^{13}$ For instance, regarding $\mathbf{1}$ and $\mathbf{2}$, respectively, for the interaction with $\mathrm{Cu}^{2+}$ we have obtained $\mathrm{K}_{\mathrm{SV}}=1.90 \times 10^{5}$ and $8.02 \times 10^{4} \mathrm{~L} \mathrm{~mol}^{-1}$, and $\mathrm{LOD}=0.24$ and $0.86 \mu \mathrm{mol} \mathrm{L}^{-1}$. As anticipated, this effect may be associated with the fluorescence quantum yield of these sensors. Compared to $2\left(\Phi_{\mathrm{FL}}=0.013\right)$, the absence of a free rotor effect on fluorescent sensor $\mathbf{1}\left(\Phi_{\mathrm{FL}}=0.350\right)$ significantly increases the fluorescence emission of the ketonic species, with direct consequences to the $\mathrm{K}_{\mathrm{SV}}$ value associated to the probe. Additionally, sensor $\mathbf{2}$ owns a bulky tert-butyl group in ortho with respect to the hydroxyl group, which may result in increased steric hindrance and a less-accessible coordination site for the cation, hampering the formation of the locked-enol tautomer. Interestingly, the molecular electrostatic potential map (MEP) images obtained for probes $\mathbf{1}$ and $\mathbf{2}$ (Figure 7) imply that the oxygen atom of the $\mathrm{OH}$ group and the $\mathrm{sp}^{2}$ hybridized nitrogen atom of the imidazole ring are both more nucleophilic in probe $\mathbf{1}$. The calculated charges (Table S1) at the oxygen atom of the $\mathrm{OH}$ group are -0.564 and -0.439 , respectively, for probes 1 and $\mathbf{2}$; likewise, at the mentioned imidazole $\mathrm{N}$ atom, charges are -0.529 and -0.512 for probes $\mathbf{1}$ and $\mathbf{2}$. Thus, with an overall more nucleophilic coordination site, probe $\mathbf{1}$ is more likely to interact with electrophilic cationic species, contributing to the formation of the locked-enol tautomer, which may reflect in higher $\mathrm{K}_{\mathrm{SV}}$ and lower LOD values.

\section{Conclusions}

The absorption and emission properties of the fluorescent sensor $\mathbf{1}$ can be rationalized in terms of an excited state intramolecular proton transfer (ESIPT), responsible for the observed large Stokes shift of $122 \mathrm{~nm}$ $\left(8719 \mathrm{~cm}^{-1}\right)$. The absorption and emission bands at 318 and $440 \mathrm{~nm}$ are, respectively, attributed to the enolic and ketonic
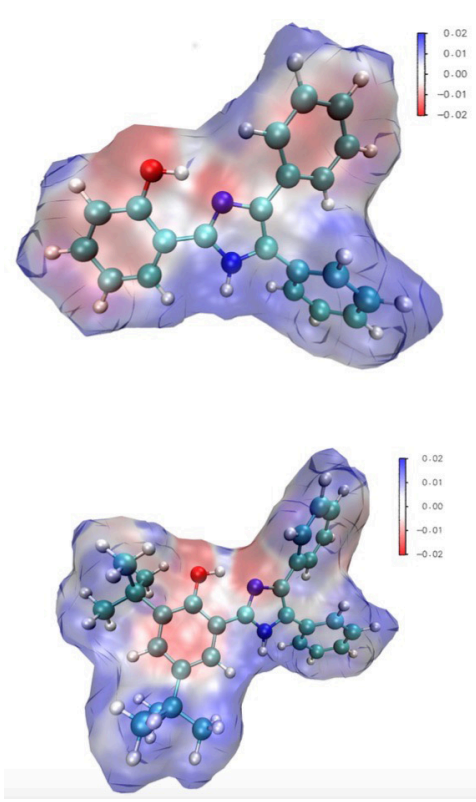

Figure 7. MEP images obtained in vacuo for fluorescent probes 1 (top) and 2 (bottom). Negative values (red-colored regions) indicate nucleophilic sites; positive values (blue-colored regions) indicate electrophilic sites.

tautomers of the molecule, the latter being generated through the ESIPT process. The addition of $\mathrm{Ca}^{2+}, \mathrm{Co}^{2+}$, $\mathrm{Ni}^{2+}, \mathrm{Zn}^{2+}$ or $\mathrm{Ba}^{2+}$ ions did not modify the free fluorescent sensor emission spectrum profile, but the addition of $\mathrm{Cu}^{2+}$, $\mathrm{Al}^{3+}, \mathrm{Cr}^{3+}$ and $\mathrm{Fe}^{3+}$ quenched the emission at $440 \mathrm{~nm}$ and, for the trivalent cations, a new emission band near $385 \mathrm{~nm}$ was observed. At $440 \mathrm{~nm}$, the obtained $\mathrm{K}_{\mathrm{Sv}}$ and LOD values were, respectively: for $\mathrm{Cu}^{2+}, 1.90 \times 10^{5} \mathrm{~L} \mathrm{~mol}^{-1}$ and $0.24 \mu \mathrm{mol} \mathrm{L}^{-1}$; for Al ${ }^{3+}, 3.00 \times 10^{4} \mathrm{~L} \mathrm{~mol}^{-1}$ and $1.07 \mu \mathrm{mol} \mathrm{L}^{-1}$; for $\mathrm{Cr}^{3+}, 1.52 \times 10^{4} \mathrm{~L} \mathrm{~mol}^{-1}$ and $3.21 \mu \mathrm{mol} \mathrm{L} \mathrm{L}^{-1}$; for $\mathrm{Fe}^{3+}$, $2.40 \times 10^{4}$ and $3.5 \mu \mathrm{mol} \mathrm{L}^{-1}$; such data indicate a greater sensitivity of the fluorescent probe towards $\mathrm{Cu}^{2+}$ ions. The signal near $385 \mathrm{~nm}$ was attributed to the formation of a locked-enol tautomer, between probe 1 and the cation. This coordinated species also suffers a collisional quenching due to interaction with metallic ions in solution, as evidenced for higher concentrations of the cations. When compared to imidazolyl-phenolic probe $\mathbf{2}$, it was rationalized that the higher sensitivity of probe $\mathbf{1}$ towards metallic ions can be attributed to a combination of fluorescent, steric and electronic factors. Even though these probes can be used to detect $\mathrm{Cu}^{2+}, \mathrm{Al}^{3+}, \mathrm{Cr}^{3+}$ and $\mathrm{Fe}^{3+}$ in the studied $\mathrm{CH}_{3} \mathrm{CN} / \mathrm{H}_{2} \mathrm{O}(95: 5, \mathrm{v} / \mathrm{v})$ system, their insolubility in water prevents the use in real water samples, for the detection of metallic ions as contaminants, for example. Nevertheless, one can resort to the introduction of a water-soluble group in the chemosensor structure, such as a carboxylic acid, ${ }^{7,29}$ to enable the water-solubility of the imidazolyl-phenolic framework, showing the potential use of such compounds for analytical purposes in environmental analysis. 


\section{Supplementary Information}

Supplementary information (MS, IR and NMR spectra for the characterization of probe $\mathbf{1}$, fluorescence spectra for the addition of $\mathrm{Ca}^{2+}, \mathrm{Co}^{2+}, \mathrm{Ni}^{2+}, \mathrm{Zn}^{2+}$ or $\mathrm{Ba}^{2+}$, calculated charges for the MEP maps) is available free of charge at http://jbcs.sbq.org.br as PDF file.

\section{Acknowledgments}

The authors thank the Fundação de Amparo à Pesquisa do Estado de São Paulo (FAPESP, RBOJr 2014/05813-2, FHB 2012/13807-7), Conselho Nacional de Desenvolvimento Científico e Tecnológico (CNPq, PHM 310669/2013-8 and 448125/2014-5) and Coordenação de Aperfeiçoamento de Pessoal de Nível Superior (Capes, FC) for financial support.

\section{References}

1. Wang, D. H.; Zhang, Y.; Sun, R.; Zhao, D. Z.; RSC Adv. 2016, 6,4640 .

2. Kundu, A.; Hariharan, P. S.; Prabakaran, K.; Anthony, S. P.; Spectrochim. Acta, Part A 2015, 151, 426.

3. Gu, Z. Y.; Lei, W.; Shi, W. Y.; Hao, Q. L.; Si, W. M.; Xia, X. F.; Wang, F. X.; Spectrochim. Acta, Part A 2014, 132, 361.

4. Xu, Z. C.; Yoon, J.; Spring, D. R.; Chem. Soc. Rev. 2010, 39, 1996.

5. Formica, M.; Fusi, V.; Giorgi, L.; Micheloni, M.; Coord. Chem. Rev. 2012, 256, 170.

6. Hao, E. H.; Meng, T.; Zhang, M.; Pang, W. D.; Zhou, Y. Y.; Jiao, L. J.; J. Phys. Chem. A 2011, 115, 8234.

7. Henary, M. M.; Fahrni, C. J.; J. Phys. Chem. A 2002, 106, 5210.

8. Kim, Y. S.; Lee, J. J.; Lee, S. Y.; Kim, P.-G.; Kim, C.; J. Fluoresc. 2016, 26, 835.

9. Lin, H.-Y.; Cheng, P.-Y.; Wan, C.-F.; Wu, A.-T.; Analyst 2012, $137,4415$.

10. Wang, J.; Pang, Y.; RSC Adv. 2014, 4, 5845.

11. Iniya, M.; Jeyanthi, D.; Krishnaveni, K.; Mahesh, A.; Chellappa, D.; Spectrochim. Acta, Part A 2014, 120, 40.

12. Qin, J. C.; Yang, Z. Y.; Yang, P.; Inorg. Chim. Acta 2015, 432, 136.

13. Orfão Jr, R. B.; Alves, J.; Bartoloni, F. H.; J. Fluoresc. 2016, $26,1373$.

14. Eseola, A. O.; Li, W.; Gao, R.; Zhang, M.; Hao, X.; Liang, T.; Obi-Egbedi, N. O.; Sun, W.-H.; Inorg. Chem. 2009, 48, 9133.

15. Wu, J. S.; Liu, W. M.; Ge, J. C.; Zhang, H. Y.; Wang, P. F.; Chem. Soc. Rev. 2011, 40, 3483.
16. Anslyn, E. V.; Dougherty, D. A.; Modern Physical Organic Chemistry; University Science Books: Sausalito, 2006.

17. Buchholz, A.; Eseola, A. O.; Plass, W.; C. R. Chim. 2012, 15, 929.

18. Jayabharathi, J.; Thanikachalam, V.; Srinivasan, N.; Jayamorthy, K.; Perumal, M. V.; J. Fluoresc. 2011, 21, 1813.

19. Kalyanasundaram, K.; J. Chem. Soc., Perkin Trans. 2 1986, 82 , 2401.

20. Benisvy, L.; Blake, A. J.; Collison, D.; Davies, E. S.; Garner, C. D.; McInnes, E. J. L.; McMaster, J.; Whittaker, G.; Wilson, C.; Chem. Commun. 2001, 1824.

21. Frisch, M. J.; Trucks, G. W.; Schlegel, H. B.; G. E. Scuseria; Robb, M. A.; Cheeseman, J. R.; Scalmani, G.; Barone, V.; Mennucci, B.; Petersson, G. A.; Nakatsuji, H.; Caricato, M.; Li, X.; Hratchian, H. P.; Izmaylov, A. F.; Bloino, J.; Zheng, G.; Sonnenberg, J. L.; Hada, M.; Ehara, M.; Toyota, K.; Fukuda, R.; Hasegawa, J.; Ishida, M.; Nakajima, T.; Honda, Y.; Kitao, O.; Nakai, H.; Vreven, T.; Montgomery, J. A.; Peralta, J. E.; Ogliaro, F.; Bearpark, M.; Heyd, J. J.; Brothers, E.; Kudin, K. N.; Staroverov, V. N.; Kobayashi, R.; Normand, J.; Raghavachari, K.; Rendell, A.; Burant, J. C.; Iyengar, S. S.; Tomasi, J.; Cossi, M.; Rega, N.; Millam, N. J.; Klene, M.; Knox, J. E.; Cross, J. B.; Bakken, V.; Adamo, C.; Jaramillo, J.; Gomperts, R.; Stratmann, R. E.; Yazyev, O.; Austin, A. J.; Cammi, R.; Pomelli, C.; Ochterski, J. W.; Martin, R. L.; Morokuma, K.; Zakrzewski, V. G.; Voth, G. A.; Salvador, P.; Dannenberg, J. J.; Dapprich, S.; Daniels, A. D.; Farkas, Ö.; Foresman, J. B.; Ortiz, J. V.; Cioslowski, J.; Fox, D. J.; Gaussian 09, Revision A.1., 2009.

22. Kim, Y. H.; Roh, S. G.; Jung, S. D.; Chung, M. A.; Kim, H. K.; Cho, D. W.; Photochem. Photobiol. Sci. 2010, 9, 722.

23. Deshmukh, M. S.; Sekar, N.; Spectrochim. Acta, Part A 2015, $135,457$.

24. Taki, M.; Wolford, J. L.; O'Halloran, T. V.; J. Am. Chem. Soc. 2004, 126, 712 .

25. Rodembusch, F. S.; Brand, F. R.; Correa, D. S.; Pocos, J. C.; Martinelli, M.; Stefani, V.; Mater. Chem. Phys. 2005, 92, 389.

26. Weerasinghe, A. J.; Abebe, F. A.; Sinn, E.; Tetrahedron Lett. 2011, 52, 5648.

27. Hsieh, Y. C.; Chir, J. L.; Yang, S. T.; Chen, S. J.; Hu, C. H.; Wu, A. T.; Carbohydr. Res. 2011, 346, 978.

28. Lakowicz, J. R.; Principles of Fluorescence Spectroscopy, $3^{\text {rd }}$ ed.; Springer: New York, 2009.

29. Henary, M. M.; Wu, Y. G.; Fahrni, C. J.; Chem.-Eur. J. 2004, 10,3015 .

Submitted: December 2, 2016 Published online: February 10, 2017 